This PDF is a selection from a published volume from the National Bureau of Economic Research

Volume Title: Housing and the Financial Crisis

Volume Author/Editor: Edward L. Glaeser and Todd Sinai, editors

Volume Publisher: University of Chicago Press

Volume ISBN: 978-0-226-03058-6

Volume URL: http://www.nber.org/books/glae11-1

Conference Date: November 17-18, 2011

Publication Date: August 2013

Chapter Title: Postmortem for a Housing Crash

Chapter Author(s): Edward L. Glaeser, Todd Sinai

Chapter URL: http://www.nber.org/chapters/c12618

Chapter pages in book: (p. 1 - 17) 


\title{
Postmortem for a Housing Crash
}

\author{
Edward L. Glaeser and Todd Sinai
}

\section{Introduction}

The remarkable boom and bust of America's housing markets during the first decade of the twenty-first century now joins the stock market gyrations of the 1920s and the dot-com bubble of the late 1990s in the pantheon of great asset market swings. The twenty-city Case-Shiller repeat sales housing price index rose 70 percent in real terms between April 2001 and April 2006, the peak of the market. By November 2011, the index had declined by 40 percent from the peak, leaving housing prices approximately where they were at the start of 2000 .

This great housing market crash did as much damage to the received wisdom about housing markets and housing policy as it did to the portfolios of households and financial institutions. Traditional economic models, with their assumptions of hyper-rational consumers with sensible assessments of future price movements, seem difficult to reconcile with price swings in markets like Las Vegas, where real housing prices rose by 71 percent in the thirty-six months before April 2006, only to fall by 65 percent in subsequent years. The unincorporated area outside Las Vegas has abundant land and little land market regulation, so how could buyers really believe that prices could stay so far above the costs of producing homes?

Edward L. Glaeser is the Fred and Eleanor Glimp Professor of Economics at Harvard University and a research associate and director of the Urban Economics Working Group at the National Bureau of Economic Research. Todd Sinai is associate professor of real estate and business economics and public policy at the Wharton School at the University of Pennsylvania and a research associate of the National Bureau of Economic Research.

For acknowledgments, sources of research support, and disclosure of the authors' material financial relationships, if any, please see http://www.nber.org/chapters/c12618.ack. 
The great housing convulsion destroyed the view that housing prices would always remain close to construction costs in unregulated markets (Glaeser, Gyourko, and Saiz 2008) and that price movements could be completely explained by changes in interest rates (Poterba 1984). Perhaps, most obviously, the crash banished the old myth that housing prices could only go up. Millions of underwater homeowners make it abundantly clear that houses are no different from any other asset in their ability to climb and crash.

Just as the crash changed our understanding of housing markets, it changed views about housing policy. While there were certainly economists who questioned the wisdom of pro-borrowing policies like the Home Mortgage Interest Deduction and the implicit subsidies enjoyed by Fannie Mae (the Federal National Mortgage Association) and Freddie Mac (the Federal Home Loan Mortgage Corporation), these policies were widely popular among politicians and voters of both parties. Subsidized mortgages were perceived not only as a tool to encourage the alleged social benefits of home ownership, but also as a path toward financial stability for ordinary Americans. Fannie Mae and Freddie Mac were supposed to be self-sufficient entities that created little risk for taxpayers.

The costs to taxpayers of bailing out these entities has been estimated at near $\$ 200$ billion, and millions of foreclosures call into question the wisdom of using subsidized borrowing to encourage asset accumulation. But there remains considerable uncertainty about what housing policy should do now, when housing markets remain weak, and in the future. A more libertarian view argues for less public intervention in housing markets. An alternative viewpoint argues for more action, at least as long as prices and construction remain low, to bolster housing markets, and hopefully thus the larger economy.

This essay is an introduction to a volume meant to make sense of the housing convulsion and its aftermath. We organized this essay, and to a lesser extent the chapters in the volume, around three broad questions. First, we focus on description. What actually happened to prices and construction during and after the housing boom? America is not one housing market, and the boom hardly hit every market equally. Even among the Case-Shiller metropolitan areas, which represent an unrepresentatively volatile set of America's cities, there were places that experienced little price movement during the boom. Between April 2000 and April 2006, real prices in the Dallas area increased by less than 2 percent.

Three of the chapters in the volume address the core facts of the boom and bust. The first one, by Todd Sinai, presents a far-ranging look at price movements at the metropolitan area level, and presents six stylized facts about housing prices movements throughout the United States. The second chapter, by Andrew Haughwout, Richard W. Peach, John Sporn, and Joseph Tracy, focuses on the supply side of the market. They document key facts 
about building and land prices during the boom, document the changing industrial structure of the building industry, and investigate the role that the supply side of the market played in determining the nature of the boom and bust.

The third chapter, by David Genesove and Lu Han, examines both prices and permitting behavior, but focuses within, rather than across, metropolitan areas. Their work illustrates that even within a single metropolitan area, some neighborhoods experienced significantly more appreciation than others. They document that the boom seems to have particularly increased prices in areas with relatively short commute times, and that the gradients of prices with respect to commuting time seems to have flattened during the bust. These facts can be interpreted as supporting the view that the boom was associated with temporarily high valuations of genuine neighborhood assets, like proximity to jobs.

The second section of this introduction focuses on the causes of the boom, and inevitably changes in credit conditions play a dominant role in the search for causes. There are, of course, alternate explanations for the boom, and we discuss some of them in this introduction. Case and Shiller have persistently argued for the importance of unrealistic expectations about future house price appreciation and, in hindsight, the assumptions of many buyers during the boom appear to have been wildly mistaken. But there are at least three reasons why irrational expectations-based explanations have garnered less attention from housing economists than credit market-based explanations.

First, it is hard to think of erroneous expectations as being an exogenous variable, appearing out of nowhere and fueling housing price growth. If we think of price growth assessments as reflecting some deeper cause, then that pushes toward understanding the deeper causes rather than the mediating force of expectations. Second, there is no clear explanation of why irrational exuberance would show up so demonstrably in some markets, like Phoenix, and not in others, like Dallas. Finally, economics has a long and valuable tradition of attempting to exhaust rational explanations for market phenomena rather than embracing human error. The focus on the rational provides discipline for economic theorizing, even if it misses important components of human behavior.

Most non-credit-related "rational" explanations of the housing boom are relatively easy to disprove. For example, traditional theories would suggest that rising incomes could increase demand for housing and explain a price increase, but incomes were not rising nearly fast enough during the 2000 to 2006 period to explain the boom. Supply limitations may explain some of the variation in prices across America's metropolitan areas, but it is hard to imagine that supply conditions were changing quickly enough during the few years of the current millennium to explain a massive housing price increase.

Conversely, real interest rates were falling during much of the 2000 to 2006 
period, and conventional models suggested that this decline might even be enough to explain a large portion of rising housing prices in many metropolitan housing markets (Mayer, Himmelberg, and Sinai 2005). In addition, there seems to have been a proliferation of easy credit during this time period, epitomized by the rise in subprime lending, that may have increased the number of people who had access to the credit needed to buy housing. As such, it is at least possible that easy credit explains a significant amount of the housing boom.

Supporters of the credit market theory note that the boom coincided with a period of time when risk spreads were extremely low by historical standards. In 2006, many lenders appear to have believed that both home buyers and the Greek government had almost no chance of defaulting. It is less clear whether this coincidence reflects a causal chain that runs from credit availability to high housing prices, or whether it reflects an overall climate of extreme optimism that simultaneously impacted home buyers, mortgage lenders and the buyers of Greek debt. Chapter 4, by Keys, Piskorski, Seru, and Vig, details the evolution of mortgage financing during the boom. They document the tremendous increase in subprime and "Alt-A" lending, and present evidence suggesting that increased securitization decreased lending standards. They document that securitization becomes more common for borrowers with FICO scores above 620, and that defaults rise, rather than fall, for borrowers with FICO scores that put them above this quantity.

The chapter by Donghoon Lee, Christopher Mayer, and Joseph Tracy (chapter 5) focuses on the rise of second liens during the boom. These second liens often made it possible for borrowers to get mortgages with essentially no money down. During the bust, these second liens create a conflict of interest between mortgage servicers who own second liens and owners of first liens. The servicers presumably have an interest to encourage payment on the second lien, even if the borrower is not servicing the first lien.

Chapter 6, by Favilukis, Kohn, Ludwigson, and Van Nieuwerburgh, then elegantly exposits the view that easy credit caused the run-up in housing prices. In their model, easy credit comes from a savings glut outside the United States. They parameterize a model and show that given their assumptions, the decrease in lending standards could have caused the price run-up. They also present some evidence linking price growth and bank loan officers' reports of their willingness to supply credit.

Chapter 7 by Glaeser, Gottlieb, and Gyourko offers an alternative take on the credit market hypothesis. They argue that there are several reasons why a conventional user cost model of housing will overstate the predicted link between credit conditions and housing prices, including elastic supply and mean reversion of interest rates. They then argue that the more modest link, predicted by a perhaps more realistic model, is supported by the longrun data and that this modest link implies that easier credit cannot explain more than a fraction of the boom in housing price and that tighter credit can similarly explain little of the bust. 
The final section of this chapter and the final chapter in this volume focuses on the future of housing policy. In this introduction we discuss briefly a broader range of public policy considerations around housing, including the Federal Housing Administration, and the Home Mortgage Interest Deduction. Chapter 8, by Dwight Jaffee and John Quigley, specifically focuses on the Government-Sponsored Enterprises (or GSEs), Fannie Mae and Freddie Mac. Jaffee and Quigley describe the history of the GSEs and their repeated crises. Their analysis suggests that the GSEs received an implicit government subsidy, and much of the benefit of that subsidy went to GSE shareholders. Moreover, even if the GSEs are not themselves responsible for the boom and bust, they seem to have done relatively little to steady the market.

The chapter then discusses broader options for the future of the GSEs and in particular the possibility of shrinking their role enormously. The authors' evidence calls into question the view that the GSEs are absolutely vital for the functioning of housing markets. It is certainly quite possible that the cost of these enterprises, at least in their current form, significantly exceeds their benefits.

The great housing convulsion is a major event for housing research - an event so significantly large that it could even herald a paradigm shift within the field. The essays in this volume attempt to collect what we know about the nature and causes of the boom. Our hope is that this provides a starting point for future major advances in housing research.

\section{The Anatomy of the Boom and Bust}

The nationwide contours of the housing market boom and subsequent bust are well known. The Case-Shiller price index may not be nationally representative, but it does capture the basic shape of events nationwide. After six long years of nominal price stagnation and real price declines from 1991 to 1997, prices began to rise again. During all but one of the first five years of the most recent decade, the twenty-city price index increased by 10 percent or more; the exception year was 2001 when, despite deep economic troubles, nominal prices still managed to increase by over 7 percent.

The Case-Shiller increase somewhat overstates the national boom because it overrepresents America's more volatile housing markets. Except for late 2004 and 2005, nominal annual price growth in the Federal Housing Finance Agency's index, which represents a far wider range of metropolitan areas, does not top 10 percent. Yet while that index typically shows annual growth rates of 6 to 7 percent, it still shows the same basic pattern of a rapid increase in price growth around the end of 2007 , followed by a sustained period of robust price increases that lasts until 2006, and steady price declines since that date.

This national pattern provides one depiction of the past decade, but it is an incomplete story. The first three chapters in this volume enrich the 
national picture first by providing subnational data (chapter 1), data on housing supply (chapter 2), and intra-metropolitan information (chapter 3). The variation within the United States is important, not just in detailing the larger picture, but providing data with which we can test various explanations of the boom and bust.

Figure I. 1 shows the relationship between changes in the Federal Housing Finance Agency (FHFA) Price index between 2001 and 2006, divided by the 2001 index level, and changes in the price index between 2006 and 2011, also dividing by the 2001 index level. We adjust for changes in the nationwide consumer price index. We deflate by the 2001 index level for both periods so that the changes are in comparable units.

The figure illustrates that the growth in prices, from trough to peak, was highly variable. Some cities, like Las Vegas, experienced extraordinary swings, while others, like Houston, were far more stable. Chapter 1 also emphasizes that the distribution of price growth has a very fat tail. The average market experienced real price growth of about 55 percent, but 57 percent of markets experienced price growth, trough-to-peak, below that amount. When Sinai weights by the number of housing units in the market in 1990, the price distribution becomes even more skewed, as some of the largest markets experienced particularly robust growth, which is one reason why the Case-Shiller price index, which is skewed toward larger markets, finds larger average growth than the FHFA index.

The ephemeral nature of the boom is also illustrated by the robust correlation between the sizes of the boom and bust. The slope of the line in the figure is -0.95 , so that if an area saw its prices rise by 50 percent between 2001 and 2006, that area's house prices were, on average, up only 2.5 percent over the entire decade. Such mean reversion is not uncommon in housing and other asset markets (Cutler, Poterba, and Summers 1991), but typically it is far milder than the figure suggests. Glaeser et al. (2011), for example, estimate a -0.32 coefficient for five-year changes on lagged figure year changes over a longer time period, which is about one-third of the coefficient shown in the picture. ${ }^{1}$ The extraordinary magnitude of mean reversion in the 2001 to 2011 period suggests that the last boom was unrelated to enduring economic fundamentals.

That heterogeneity is itself an important fact about the boom, in part because it relates to different theories about the boom's cause. If this enormous heterogeneity is to be compatible with a common national shock to housing demand, caused perhaps by a common national shock to credit conditions, then there must be extremely large differences in housing supply, as suggested by Glaeser, Gyourko, and Saiz (2008). Alternatively, this heterogeneity might mean that a common national factor, like easier credit,

1. These results are not exactly comparable since they also control for year and area fixed effects, but even without those the estimated mean reversion levels are far smaller. 


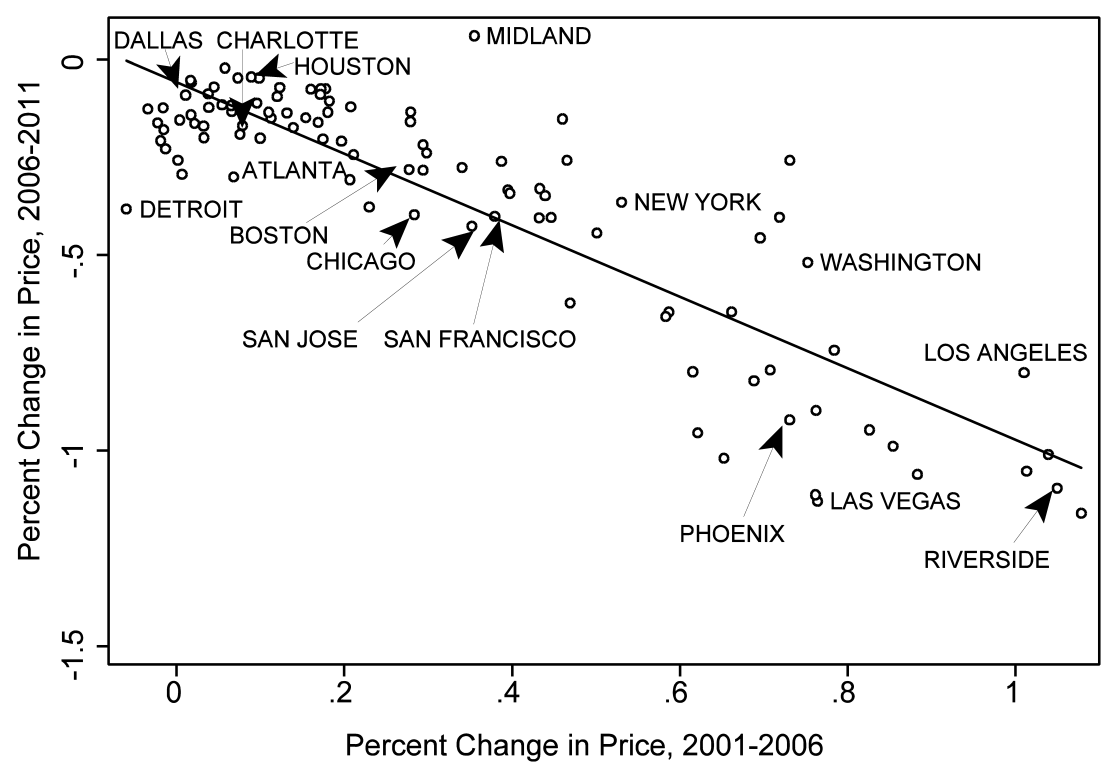

Fig. I.1 Percent house price growth (2001-2006) versus percent house price declines (2006-2011) by housing market

Note: House price growth calculated from the Federal Housing Finance Agency's House Price Index.

had different impact in different areas depending on local factors, such as the number of borrowers that were previously unable to access credit, as in Mian and Sufi (2009). A final explanation is that the booms were fueled by location-specific factors, perhaps including unrealistic expectations about local long-run trends that were not driven by any common national shock.

One clue offered by the heterogeneous price changes is that the places that boomed in the 2000s also boomed during the previous run-up in housing prices during the late 1980s. While the magnitude of the more recent price rise is far larger, there is a strong correlation between boom markets across the two episodes. This fact is compatible with the view that housing supply elasticity, which is presumably relatively constant over time, helps explain the cross-area heterogeneity. It is only compatible with the hypothesis that emphasizes a common national shock interacting with different local conditions, if indeed it was essentially the same national shock that operates during both periods, such as easier credit. If the boom was the result of lots of little local shocks, then there would have to be some reason why those shocks were so similar in the 2000s and the 1980s.

The cross-area heterogeneity is also helpful in testing the hypothesis that changes in underlying fundamentals can explain the boom. The Sinai essay addresses fundamentals both by controlling for rents and by controlling 
for underlying economic variables such as local income levels. Neither of these variables can explain much of the variation in prices over the boom, which pushes us toward theories that reflect the cost of capital or expectations about housing price appreciation - both of which should impact the price-to-rent ratio - and away from theories that emphasize changes in the fundamental demand for housing in particular areas.

A final interesting geographic fact is that the price growth was disproportionately present in coastal metropolitan areas. While there were some inland areas, such as Las Vegas, that experienced extreme price movements, overall, the interior of the country was far more stable. The coastal areas typically have more restrictions on housing supply, and more robust local economies that have shown remarkable resilience over many decades. The geographic clustering also reminds us that at least geographically proximate markets do seem to be somewhat linked, as documented by Sinai and Souleles (2005).

The Genesove and Han chapter focuses within metropolitan areas. During the latest boom, there was more price growth in the center of metropolitan areas, although that was not the case during the 1980s (Glaeser and Gottlieb 2012). The Genesove and Han chapter documents that the prices declined more sharply with commuting time during the boom than after it, which also suggests that prices rose more sharply close to employment centers.

Genesove and Han suggest a supply-side story for explaining this effect. Areas that are further away from employment centers effectively have more land in which to deliver housing. That extra supply can mute the price impact of demand increases. An alternative view suggests that price growth during the boom was associated with overly optimistic assessments of the value of urban assets, including access to core employment sectors. If these assets were temporarily overvalued during the boom, then we should expect to see more of a price decline in these areas during the bust.

While the examples of Phoenix and Las Vegas during the boom showed that extreme price growth was still possible in areas with apparently elastic supply, supply is still important both in shaping price growth and in determining the long-term real consequences of the boom. After all, the supply elasticity determines the extent to which a temporary price boom translates into real investment in housing and commercial real estate throughout the country. Understanding the magnitude of oversupply during the boom is also important if we are to estimate how long it will take for the American construction industry to resume more normal building levels.

Chapter 2 begins by putting the housing boom of the last decade into a broader historical perspective. Measured by housing starts per capita, the construction boom never reached the heights hit in the 1960s, 1970s, and 1980s. However, while those booms had a relatively short duration, and were followed by short, sharp downturns, the more recent building boom 


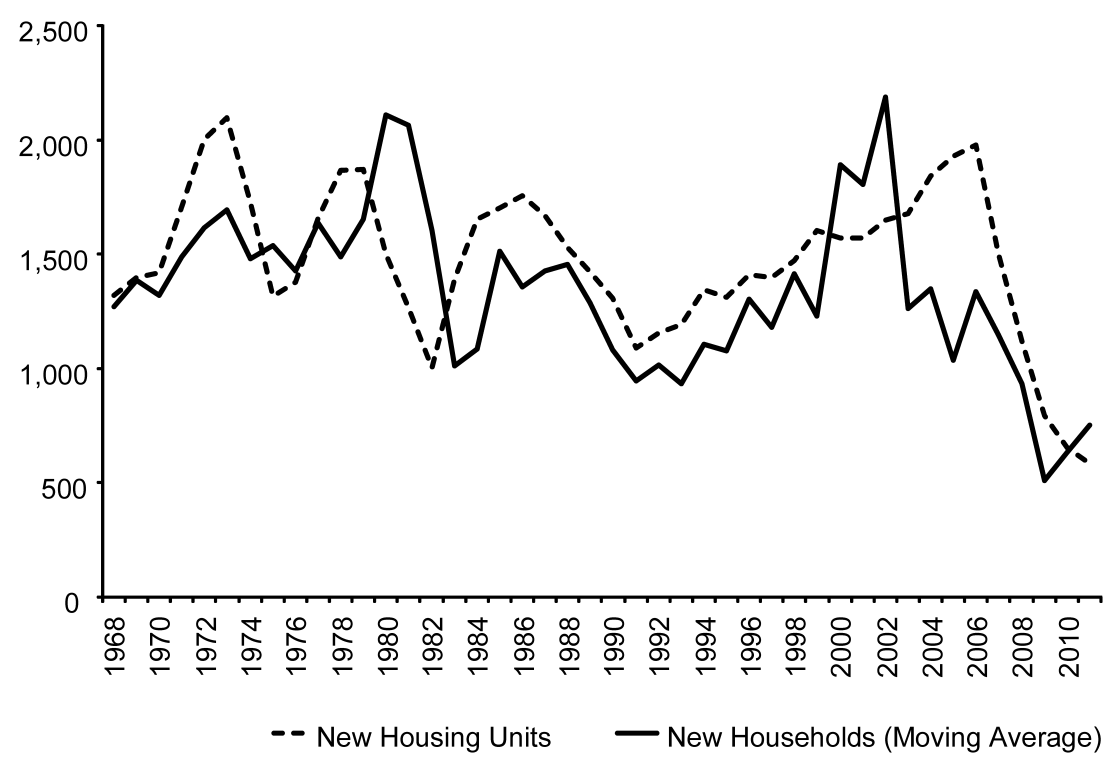

Fig. I.2 Number of new housing units and number of new households, 1968-2011

Notes: Numbers in thousands. "New Households" is an average of the current year, the previous year, and the next year.

lasted for almost fifteen years. The construction bust after that boom has been more extreme than during the earlier upturns, perhaps because this boom lasted for so many years. As a share of gross domestic product, the recent building boom was fully as big as in earlier years, which reflects higher building costs and the larger structures that have become more prevalent. Moreover, the recent boom was almost all driven by increases in singlefamily, not multifamily, construction.

The amount of building needs to be related to the rate of household formation. Figure I.2 shows the long-run paths of household formation and changes in the number of new housing units in the United States. During the earlier booms, increases in building were matched with increases in the numbers of new households. During the more recent boom, construction occurred without any similar increase in number of households.

Haughwout et al. emphasize the changing demographic trends within America to explain the shifts. In earlier decades, the number of younger Americans was growing rapidly, as the baby boomers moved into adulthood. In recent years, the growth in younger age cohorts has been modest, but there were increases in the numbers of older Americans. Indeed, this demographic shift led Mankiw and Weil (1989) twenty years ago to predict a great housing bust. The fact that the building boom occurred despite the aging of America is fairly remarkable. 
Haughwout et al. also illustrate the mismatch between construction and population growth at the state level. Throughout the 1990s, there is a fairly tight connection between overall state population growth and the number of housing starts. Between 2000 and 2005, however, housing starts seemed to be much higher than would be warranted due to population growth in many states, such as Arizona and Nevada. In other areas, such as California, population growth and housing starts remain closely connected.

This surfeit of building meant that there was a great deal of excess housing, even during the height of the boom, and a significant increase in nonseasonal vacancy rates. The vacancy rates were particularly high in the South. Typically, rising prices are associated with supply shortfalls, but during the boom the supply response was so enormous that housing was actually abundant. It remains puzzling that this glut did not do more to limit housing price growth.

The Haughwout et al. chapter also examines changes within the industrial organization of the building community. During the boom, building was increasingly dominated by larger builders and those builders increasingly built up large inventories of land. The consolidation of the building industry is striking. In 1990, the ten largest builders accounted for less than 10 percent of US construction, but by 2005, they were responsible for over 22 percent of American building. The authors emphasize the large number of company acquisitions over this period, and that larger builders typically rely less on bank financing, which means that they may face less scrutiny toward their construction projects.

Their large land inventories meant that the builders had also become big land speculators. Well-financed, presumably well-informed building companies were accumulating vast amounts of land. This presumably suggests that beliefs about increasing land values were quite widespread - it was not just ordinary homeowners who were gambling on real estate markets during this time period - and it meant that many builders found themselves in dire financial straits after the boom, leading to further distress within that industry.

\section{The Causes of the Boom and Bust: Easy Credit and Other Explanations}

It is easier to describe the events of the 2001 to 2011 decade than it is to explain them. The price boom was so much more extreme than during previous periods that it is hard to find exogenous forces that could possibly have explained such a serious price fluctuation. Classical explanations of price fluctuations emphasize changes in fundamentals, such as sizable shocks to housing demand created by rising income levels, or shocks to housing supply, such as increased limitations on construction. Yet it is hard to find such fundamental shifts. Certainly, the American economy was not experiencing a particularly unusual boom over these years. 
Supply constraints do not appear to have been particularly tight in many boom areas, such as Las Vegas and Phoenix. While there were certainly stories suggesting that land was becoming less available in the Las Vegas region (Nathanson and Zwick 2011), the massive numbers of new homes built in the area makes it hard to believe that restrictions on supply were becoming all that onerous. Relatively flat rents also belie the view that changes in the demand and supply of housing drove the housing price boom.

An alternative view emphasizes the role of credit markets in driving the change. Chapter 4 by Keys, Piskorski, Seru, and Vig describes the evolution of mortgage financing during the boom. During the early years of this millennium, mortgage originations increased dramatically, but the initial wave was overwhelmingly originated by GSEs. The GSE mortgage originations appear to have increased fivefold, from roughly $\$ 500$ billion to $\$ 2.5$ trillion during their peak in 2002. That peak largely represented mortgage financing during an era of historically low interest rates.

Starting in 2002, there was a substantial increase in Alt-A and subprime mortgages originated through 2005 and 2006. While the GSEs remained the largest mortgage originator during this time period, the combined class of Alt-A and subprime mortgages exceeded GSE originations by 2005. After 2006, these riskier classes of mortgages declined dramatically.

As subprime and Alt-A mortgages became more prevalent, they were also increasingly securitized. The securitization rate for this class of mortgages was below 50 percent in 2001 and increased to over 90 percent by 2007. This time-series fact seems to support Keys, Piskorski, Seru, and Vig's contention that an increasing ability to securitize mortgages helped enable the vast flow of Alt-A and subprime credit to mortgage borrowers.

Over this period of increased securitization, some — but not all — characteristics of nonagency debt also evolved. There was little change in FICO scores over the boom, and the gap between prime and subprime lenders in this important measure of riskiness remained relatively constant. However, second liens became more important in the nonagency market, and average cumulative loan-to-value ratios eventually reached over 95 percent, meaning that borrowers were putting very little money down. Among the same group of borrowers, an increasing share of loans was made without complete documentation, further supporting the view that credit became more available in this group.

Keys, Piskorski, Seru, and Vig then document the apparent increase in the ease of securitizing risky mortgages. The time between origination and securitization fell from sixteen months to six between 2000 and 2006, suggesting that ability to pass along even risky mortgages had steadily increased. At the same time, the number of tranches in the typical subprime mortgage pool was increasing. Increasing numbers of tranches were often associated with a greater transformation of initially quite risky mortgages into pools of mortgages that appeared much safer because they contained the safest 
tranches of the mortgage pool. Of course, after the mortgage bust, many of those apparently safer tranches proved to remain quite risky.

Some of the most compelling evidence for the importance of securitization in producing lax credit is the evidence for a discontinuity in the treatment of borrowers around the 620 FICO score. In many cases, the FICO score of 620 has proved to be a rule of thumb that determines whether a mortgage can be securitized. Keys, Piskorski, Seru, and Vig show in their loans data that there is a vast discrete jump in the amount of prevalence of securitized low documentation mortgages at the 620 FICO score point, which seems to confirm the view that this was a real cutoff. The time to securitize also declines discretely at the 620 point.

If securitization leads to a reduction in the level of lender scrutiny, then we might expect to see a jump in the level of scrutiny for mortgages with borrowers under the 620 FICO point because, below that level, lenders expect to carry the risks of the mortgage themselves. Keys, Piskorski, Seru, and Vig do find that there are substantially higher delinquency rates just above the 620 FICO score cutoff. While it is in principle possible that this discontinuity reflects rules of thumb other than securitization per se, it is at least quite reasonable to think that securitization was one of the reasons why delinquency rates increase at the 620 point.

Keys, Piskorski, Seru, and Vig also examine the rash of foreclosures since the crash. Many authors have argued that there are too many foreclosures, and too few loan modifications, even relative to the interests of lenders. The significant losses involved in foreclosure would seem to create strong incentives to modify loans, although it is possible that it is just too difficult to identify borrowers for whom modification would actually deter default. Widespread modifications have the problem of reducing lender revenues for many mortgages that would have stayed current without any modification. An alternative hypothesis is that securitization makes renegotiation more difficult by creating diverse ownership and agents who are likely to just follow the letter of the contract.

Keys, Piskorski, Seru, and Vig show that independent servicers tend to foreclose more quickly. They also find that banks are less likely to foreclose on mortgages that they hold themselves. These facts seems to link securitization with the large numbers of foreclosures, which suggests an added reason to be wary of the securitization process.

In chapter 5 Lee, Mayer, and Tracy look at one particular aspect of the credit boom - the rise in second liens. There are two prevalent forms of second liens: home equity lines of credit (or HELOCs) and closed-end second liens (CES). The HELOCs are typically given to more creditworthy borrowers and are often used to supplement standard forms of borrowing, such as credit card debt. Closed-end seconds are more often given to riskier borrowers, and these are more often used to actually fund the purchase of the home, allowing the borrower to put relatively little of their own money down. 
Both forms of second liens increased dramatically over the boom. The HELOCs remained the larger form of second lien, but CES increased dramatically in its share of overall second lien balances. Closed-end seconds were particularly common after nonprime first loans, and they were particularly common in areas that experienced extreme price fluctuations during the boom. They seem to have been a significant part of the credit explosion that accompanied the boom.

Delinquency rates for CES liens are quite high and close to the delinquency rates for subprime mortgages. Delinquency rates for HELOCs are substantially lower, and more comparable to the delinquency rates on auto loans. The delinquency rates for both types of second liens that were originated at the peak of the boom (2004 to 2006) are much higher than second liens originated during earlier years, which at least suggests that lending standards had been substantially relaxed for these forms of credit as well.

One of the great puzzles about second lien delinquency is that in principle, they should be more likely to be delinquent than first mortgages, which are technically senior debt. Yet in many cases, borrowers keep their second mortgages current while defaulting on their first mortgages. Lee, Mayer, and Tracy document this fact and present three interesting explanations for why this might be occurring, including the government-created incentives to default on primary mortgages and personal liability for second liens.

The Favilukis, Kohn, Ludwigson, and Van Nieuwerburgh chapter goes a step further back and attempts to understand the explosion of credit that was contemporaneous with the bubble. They argue that there was an increase in the supply of credit coming from outside the United States. They document the tremendous flow of credit into the United States during the boom years, and the relatively low interest rates during the time period.

They then perform panel regressions where they link loan officers' perceptions of the ease of supplying credit with price increases. While it is possible that rising house prices led loan officers to increase the supply of credit rather than the reverse, these regression results support the idea that there is a link between credit availability and the price growth during the boom.

In chapter 7 Glaeser, Gottlieb, and Gyourko present a somewhat contrarian view of credit and the boom. While they do not dispute there was a substantial increase in the amount of lending during the boom, they argue that neither theory nor empirical work suggests that the level of price increases can be easily explained by the changes in credit. They suggest that standard rational models of home-buyer behavior suggest a relatively weak link between credit variables and home prices. One reason for this weak link is that buyers who purchase homes during easy credit periods should expect some mean reversion of interest rates and credit conditions, which should cause them to expect to sell during periods when credit is less available.

The authors provide some empirical work suggesting that the historic link between real interest rates and housing prices is in line with the predictions 
of a simple rational model and far too small to explain the boom. Finally, they also provide some evidence on aggregate changes in loan-to-value ratios and loan acceptance ratios. While there were significant changes in these variables in specific subsets of the borrower population across the whole US market, these measures of credit availability do not appear to have changed enough to explain the boom in prices.

Chapter 7 also reminds us that the bust happened despite a period of persistently low interest rates. However, it is possible that other changes in the credit market may have helped prod housing market declines. For example, subprime borrowers found it more difficult to borrow during the bust. Moreover, the decline coincided with the introduction of new credit instruments, such as synthetic collateralized debt obligations, that made it easier for some investors to short the housing market. Of course, that introduction is itself endogenous and may reflect the desire of some savvy investors to short a market that seemed to them to be headed for a fall.

These facts do not imply that widespread credit availability was not important to the boom. But the link between credit and housing price growth does not seem to be sufficient to be the sole explanation. Instead, it seems more likely that credit interacted with other conditions, like buyer overoptimism, during the 2000 to 2006 period, and helped create the cocktail that spurred growth.

\section{Public Policy in the Wake of the Crash}

Even if we do not fully understand the causes of the great housing convulsion, the convulsion itself seems to call out for rethinking Federal housing policy. The government-sponsored enterprises are the most pressing area for reform. They were nationalized in the wake of their collapse, and no one has argued that the status quo, where they remain wards of the state, is a reasonable permanent solution. The Jaffee and Quigley chapter, which ends this volume, provides an overview of the history of the GSEs and a discussion of policy options going forward.

Fannie Mae got its start in the Great Depression to provide liquidity for mortgage lenders. It first acquired private shareholders in 1954 and was privatized in 1968. In 1970, Freddie Mac was create to generate competition for Fannie Mae. Together, they insure trillions of dollars of mortgages, bearing the potential default risk. At their height, they collectively also held $\$ 1.5$ trillion worth of retained mortgages, which creates added interest rate risk.

While federal officials repeatedly attempted to signal that the federal government was not liable for the GSE debt, the market never seemed to believe these signals. Fannie and Freddie were regularly able to borrow at interest rates that were remarkably close to those paid by the US Treasury and far below interest rates paid even by the most secure AAA company. 
The natural conclusion is that the market was sure that these entities would be bailed out, and of course, subsequent events have proven those investors to be correct.

The combination of private ownership, and the ability to borrow with an implicit Federal guarantee, seems almost certain to lead to too much risktaking. Shareholders stood to profit enormously when times were good, and the government bore the risk during downturns. The eventual collapse of the companies seems almost inevitable.

Yet the path forward seems unclear. One option is complete privatization. Yet the entities were private before the crash. It is not clear that the government can commit itself not to bail out private entities in the future. A second approach is to provide public backstop insurance for a fee, which recognizes that the government will be on the hook in the case of a catastrophe. A third approach is to keep the entities in public hands, and to allow them to gradually be competed into irrelevance. One proposal is for them to gradually decrease the upper limit on conforming loans. A second proposal is to increase the origination fees, which will hopefully ensure that they compete poorly relative to the private sector.

All approaches carry risks. The government may charge too little for catastrophic insurance, which will mean that the subsidization of these entities continues. A purely public entity may end up charging excessively low origination fees for political reasons, which will also lead to taxpayer losses. A purely private alternative may also lead to subversion of the political process. The ultimate decision about the appropriate path forward depends as much on an assessment of political risk as any appraisal of the housing market.

The great housing convulsion also raises other policy questions. How much should the government be intervening to reduce foreclosures? Chapter 4 suggests that securitization may have led to too few loan modifications. If foreclosures create externalities, as suggested by Campbell, Giglio, and Pathak (2011), this may lead to further social losses. This creates some case for federal encouragement of loan modifications, but modification programs can also lead to social waste, especially if they end up encouraging delinquencies, as suggested by Lee, Mayer, and Tracy.

The great housing convulsion even calls into question the Federal policy of subsidizing home borrowing through the home mortgage interest deduction. If subsidized borrowing leads to excessive risk-taking by ordinary Americans, then this policy may lead to a foreclosure society rather than an ownership society. Reconsidering such massive long-standing housing policies seems like a critical topic for future research.

\section{Conclusion}

The chapters in this volume examine the nature of the housing boom and its causes. The boom was not uniform. It was far stronger in some regions 
than in others. The regions that experienced the biggest booms between 2001 and 2006 have also experienced the biggest busts since then. The boom was associated with a massive increase in construction, as well as price fluctuations. Indeed, the fact that abundant construction in markets like Phoenix, Miami, and Las Vegas seemed to do so little to moderate the price boom remains an enduring puzzle. The construction boom and bust reminds us of the ability of the housing market to drive shifts in the real economy.

Easy credit, enabled by securitization and a wave of foreign lending, remains the most plausible explanation of the boom, yet even this explanation leaves many holes. The price growth seems to have been too high, at least relative to historic precedent and standard rational models, to be explained by the flow of lending. It seems likely that easy credit was necessary for the boom, but it seems unlikely to be a sufficient cause. Other forces were also at work.

The policy path forward also remains murky. The GSEs do seem to be a critical area of policy interest, but it remains unclear whether they should be privatized or kept as public entities. Hopefully, whatever path is chosen will reflect a serious understanding of the risks that occur when a private profitmaximizing entity enjoys an implicit government guarantee. It is also reasonable to rethink other Federal interventions in the housing market, such as the home mortgage interest deduction, given that we have been given such compelling evidence that home prices can fall dramatically as well as rise.

But while policy questions remain open, the events of the past decade make one point clearly. Housing is a critical part of the American economy and its study cannot be seen as a minor topic. Until we better understand housing markets and their fluctuations, we seem doomed to repeat the mistakes of the past and we risk again experiencing a painful real estate roller coaster that carries financial markets along in its wake.

\section{In Memoriam}

Our friend and colleague John Quigley passed away in April 2012, after his contribution to this volume was written. John contributed greatly to the project represented by this book, as he did in so many ways throughout the field of housing economics. His presence will be greatly missed, but his intellectual legacy will remain vibrant.

\section{References}

Campbell, John, Stefano Giglio, and Parag Pathak. 2011. "Forced Sales and House Prices.” American Economic Review 101 (5): 2108-31. 
Cutler, David, James Poterba, and Lawrence Summers. 1991. "Speculative Dynamics." Review of Economic Studies 58 (3): 529-46.

Glaeser, Edward L., Joshua D. Gottlieb, and Kristina Tobio. 2012. "Housing Booms and City Centers." American Economic Review 102 (3): 127-33.

Glaeser, Edward L., Joseph Gyourko, Eduardo Morales, and Charles Nathanson. 2011. "Housing Dynamics.” Working Paper, May 20.

Glaeser, Edward L., Joseph Gyourko, and Albert Saiz. 2008. "Housing Supply and Housing Bubbles.” Journal of Urban Economics 64 (2): 198-217.

Himmelberg, Charles, Christopher Mayer, and Todd Sinai. 2005. "Assessing High House Prices: Bubbles, Fundamentals and Misperceptions." Journal of Economic Perspectives 19 (4): 67-92.

Mankiw, Gregory N., and David N. Weil. 1989. "The Baby Boom, the Baby Bust, and the Housing Market." Regional Science and Urban Economics 19 (2): 235-58.

Mian, Atif, and Amir Sufi. 2009. "The Consequences of Mortgage Credit Expansion: Evidence from the US Mortgage Default Crisis." Quarterly Journal of Economics 122 (4): 1449-96.

Nathanson, Charles, and Eric Zwick. 2011. "Arrested Development: A Theory of Supply-Side Speculation in the Housing Market." Working Paper.

Poterba, James. 1984. "Tax Subsidies to Owner-Occupied Housing: An AssetMarket Approach.” Quarterly Journal of Economics 99 (4): 729-52.

Sinai, Todd, and Nicholas Souleles. 2005. "Owner Occupied Housing as a Hedge against Rent Risk.” Quarterly Journal of Economics 120 (2): 763-89. 